\title{
Stocks and Mutual Funds: Common Risk Factors?
}

\author{
Paulo Rogério Faustino Matos ${ }^{\dagger}$ \\ Federal University of Ceará \\ José Alan Teixeira da Rocha ${ }^{\Omega}$ \\ BNB Northeast Bank
}

\begin{abstract}
In this article we analyze the capacity to price and predict the returns of stock mutual funds in the Brazilian market, using the capital asset pricing model (CAPM) and the factor models developed by Fama and French (1993) and Carhart (1997). The first results show an expected outcome: better pricing performance of the CAPM vis-à-vis the other models for mutual funds that track the São Paulo Stock Exchange Index (Ibovespa). The main contribution, however, consists of the evidence that the factor models perform better in pricing and in-sample forecasting of the returns of funds that outperform the market and have higher total assets. This evidence suggests that models should be constructed based on specific factors for investment funds that capture these effects, which is corroborated by the preliminary results in Linhares, Matos and Zech (2009).
\end{abstract}

Keywords: capital asset pricing model; factor models; pricing ability; in-sample prediction; mutual funds.

Received in 12/19/2008; revised in 02/18/2009; accept in 03/12/2009.

Corresponding authors:

${ }^{\dagger}$ Adjunct Professor in the programs of graduate and post-graduate in economics of the UFC (CAEN) Address: Rua Alberto Feitosa Lima, 100, ap 200 -

Fortaleza, CE-Brazil.

E-mail:paulomatos@caen.ufc.br

Telephone: (85) 91648285

\footnotetext{
${ }^{\Omega}$ Superintendent of Area Resource Management of $B N B$

Address: Rua Antonio Parreiras, 148, Apto 602,

Rio de Janeiro - RJ, CEP: 22411-020

e-mail: jalantr@ig.com.br

Telephone: (85) 3299-3061
}

Editor's note: This paper was accepted by Antonio Lopo Martinez. 


\section{INTRODUCTION}

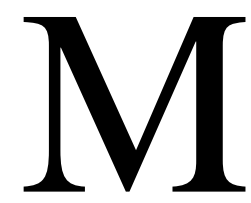

utual funds in the modern sense first arose in Belgium in the early nineteenth century. They soon spread to other European countries, and then within a half century to the United States.

In Brazil, although the first investment fund was established only 51 years ago, by the end of 2007, according to the National Association of Investment Banks (ANBID), the financial volume of these funds was over $R \$ 1$ trillion, representing over $60 \%$ of the total funding of the financial system, considering demand and term deposits. In this respect, Brazil has the highest ranking among emerging economies, in tenth place in the world.

Because of the evident relevance of mutual funds to the global financial market, ${ }^{1}$ strategies to choose investment portfolios have been a fertile ground for research. One of the pioneering works of modern portfolio theory was Markowitz (1952), according to which if it is basically assumed that all rational investors consider the first two moments of the probability distribution of returns on an asset, the result obtained is what a common optimal risky portfolio can have offered to all investors regardless of their level of risk aversion. Under a scenario favorable to the adoption of a passive investment strategy, there has been a strong expansion of this segment of investment funds in the country, corroborating the asset pricing theory. This context justifies the growing need to study models that are able to explain and predict the return on these investments, which enable diversification at a smaller cost.

In this sense, our main objective here is to show the pricing ability (explanatory power) and analyze the in-sample predictability of the returns of mutual funds in the Brazilian market, using the capital asset pricing model (CAPM) proposed by Sharp and Lintner (1964), the three-factor model developed by Fama and French (1993) and its main extension, the fourfactor model presented by Carhart (1997). The choice of these models is justified because they are considered the main models used to evaluate stock market performance in a cross-section context. $^{2}$

The results obtained here suggest that the performance of these models in terms of pricing and forecasting depends on the pattern of mutual funds in Brazil. To put it succinctly, the factor models better capture the risks associated with investment funds with higher stockholders equity and with a greater performance gap with the Ibovespa. This improvement, however, does not appear to be sufficient, which can indicate the need to construct factor models $a ̀$ la Fama and French that accommodate the specific anomalies of the investment fund market.

This article is organized into five sections including this introduction. The next section presents a review of the literature, while Section 3 describes the empirical exercise, Section 4 presents the results and Section 5 concludes.

\footnotetext{
${ }^{1}$ More than $90 \%$ of all operations to finance/invest in companies in the world are linked directly or indirectly to investment funds.

${ }^{2}$ It is possible to observe in Fama and French $(1992,1993$ and 1996) the excellent performance of this model in the time-series dimension as well.
} 


\section{REVIEW OF THE LITERATURE}

\subsection{Theoretical Models for Pricing Assets}

Vargas and Leal (Cassettari, A., 2006) state that "one of the most important questions about financial theories involves the efficient management of portfolios." In general, those involved with the theory of portfolios always are concerned with the efficient allocation of capital. Thus, this is a longstanding subject of study that still remains current.

The intuition expressed in the first studies on the subject was correct: that the focus was on identifying its two basic concepts of risk and return. Nevertheless, only with Markowitz (1952) were the bases laid down of what has become known as modern portfolio theory. The most relevant point of this theory was to place the risk-return relationship on solid mathematical foundations. Besides this, one of the most important consequences of the work of Markowitz (1952) was the more precise notion of diversification, i.e., that proper diversification could reduce, and even (at least theoretically) eliminate risks.

Markowitz (1952) started from the simple idea that all investors deal with two uncertainties: expected return and risk, measured by the variance of this return. The basic rule is that these two factors are in reality the only ones to be considered in choosing a portfolio, and that return is the factor desired by the investor and variance the undesired one. Therefore, a rational investor will want to maximize the desirable factor and minimize the undesirable one. The choice of the risk-return function seeks to deal with financial assets quantitatively. This simplification of realty permits investors to make their investment decisions in an easy and intuitive way, enabling, for example, the use of an indifference curve to facilitate visualization of the most appropriate asset for a particular investor, given his level of predisposition to risk.

Based directly on the portfolio selection theory of Markowitz (1952), Sharpe (1964), Lintner (1965) and Mossin (1966) developed the capital asset pricing model (CAPM). The CAPM shows that the rate of return in equilibrium of risky assets is a function of their covariances with the market portfolio.

Bodie and Merton (2002) point out that "the fundamental idea behind the CAPM is that in equilibrium the market rewards people for bearing risk." Bonomo (Ribenboim, G., 2004) stresses that the CAPM "was the first and most famous and utilized model for pricing assets." Thus, this is the first asset pricing model discussed in the present study. Because it is one of the most used models both in the capital market and in corporate finance to define the cost of capital, the CAPM is also on of the most studied in the area of finance. Since its formulation in the mid-1960s, many researchers have tried to test it empirically, to defend or attack it. Various extensions have been suggested in an attempt to improve it, by elucidating possible new risk factors and creating refined versions able to forecast future returns more precisely. Therefore, we examine some works in this area, both in the American and Brazilian markets, to investigate whether the latter market behaves according to the models formulated for developed markets.

However, despite the extensive bibliography on the subject, the results are still controversial. The empirical evidence indicates there are other risk factors besides beta, which represents the market in the CAPM, but once again the results are not unanimous. The hypotheses for returns that are anomalous to the model derive not only from relaxing the rational premises of the original CAPM, but also consider the possibility of irrational behavior by market agents. According to the CAPM, the expected return of any asset is a linear function of only three variables: beta (coefficient of sensitivity of the asset in relation to the 
market return), the risk-free rate of return and the expected market rate of return, according to the formula below.

$$
E\left(R^{i}\right)-R^{f}=\beta_{i} \cdot\left[E\left(R^{\eta}\right)-R\right]
$$

where:

$\left(R^{i}\right)$ - return of asset $i$.

$R^{f}$ - risk free rate of return.

$R^{m}$ - the market rate of return.

$E($.$) - expectation operator.$

$\beta_{i}$ - the sensitivity coefficient of the return of asset $i$ to the market return.

The CAPM is based on some strong premises, among them:

i) Investments are short-term: all investors plan for only one period, ignoring what can happen over the long run.

ii) There are no taxes or transaction costs on trading.

iii) All investors use the portfolio selection model of Markowitz.

iv) Investors' expectations are homogeneous.

At the end of the 1960s, the construction of the database of the University of Chicago - Center for Research in Securities Prices (CRSP) - and advances in computational power allowed the first tests of the CAPM, to see whether its theoretical success was backed up by empirical success.

The conclusions of these works indicated that the CAPM was poorly specified and introduced other important factors to determine the expected return of assets. Based on these criticisms, various authors alternatively sought to test the model taking into consideration the impossibility of obtaining a portfolio accurately representing the overall market return.

This prompted researchers to seek other routes instead of only worrying about finding a true market portfolio, and to accept market indexes as satisfactory approximations. They started to investigate the behavior of systematic anomalies detected in the formation of asset prices and not explainable by the CAPM.

Many studies were carried out trying to identify other factors besides the CAPM variables, better able to explain the return of assets. As a theoretical and empirical alternative to the CAPM, Ross (1976) presented a model based on arbitrage pricing theory (APT), whereby the formation of equilibrium prices of assets is a result of the systematic influences of economic factors, even if they are not directly observable. Although it establishes a linear relation of the expected returns o assets, this model does not need the simplifying hypotheses of the CAPM, contemplating situations of disequilibrium in the economy as long as there are no arbitrage opportunities. The true market portfolio is no longer important and new discussions arise over what other economic factors could affect the expected return of assets, since the model does not determine which factors are relevant or the respective risk premiums.

Other authors also developed factor models. Fama and French (1992, 1993, 1995, 1996) showed that the effects of the book-to-market value ratio and firm size absorb the majority of the anomalies that invalidate the CAPM. They proposed an alternative model, described below, which includes two other factors besides the market factor: the "small minus 
big" (SMB), related to firm size, and the "high minus low" (HML), related to the book-tomarket ratio.

$$
E\left(R^{i}\right)-R^{f}=\beta_{i} \cdot\left[E\left(R^{m}\right)-R^{f}\right]+s_{i . .} E(S M B)+h_{i .} E(H M L)
$$

where:

$S M B$ - real return of a zero-cost portfolio formed of small firms minus big ones, as measured by market capitalization.

$H M L$ - real return of a zero-cost portfolio of firms with a high (book/market) minus low index price.

$s_{i}, h_{i}$-coefficients to be estimated from the multiple regressions performed from the sample data.

Fama and French (1998) confirmed that these effects were present in various countries in the period from 1975 to 1995.

From an empirical standpoint, this model has been very successful in explaining the behavior of stock returns in cross-sectional studies, in the American and some other developed financial markets. Hence, there is evidence of risks associated with stocks that are not captured by the market index, but are by the other two factors proposed by Fama and French.

This question is of great importance for the following reason: if a portion of nonsystematic risk, associated with each stock, can be entirely diversified, then the model suggests that the market index is not able to fully capture all the systematic risk to which all stocks are subject, to a greater or lesser extent. In other words, there are other systematic risk factors for the stock market not yet identified and that are synthesized by factors related to investment strategies.

Other studies have attempted to identify other factors that could complement the explanation of return on financial assets. Jegadeesh and Titman (1993) identified the momentum effect, whereby stocks with low returns in the past three to twelve months tend to decline in performance in the next three to twelve months, while those with extraordinary returns in the same period tend to maintain their high returns in the next three to twelve months. According to the authors, the most profitable strategy is to buy stocks based on their good performance over the past six months and hold them for six more months. The same authors (Jegadeesh and Titman (2001)) found that momentum strategies continued to be profitable even after the publication of their first study and argued that the existence of the momentum effect in the short term is the result of a delayed reaction of agents to the available information.

Motivated by that finding, Carhart (1997) analyzed the performance persistence of mutual funds over the period from 1962 to 1993, using as one of his models the classic threefactor model of Fama and French (1993), but adding another factor to capture the momentum effect documented by Jegadeesh and Titman (1993), according to the following formula.

$$
E\left(R^{i}\right)-R^{f}=\beta_{i} .\left[E\left(R^{m}\right)-R^{f}\right]+S i . . E(S M B)+h_{i . E}(H M L)+p_{i .} E(P R 1 Y R)
$$


where:

PRIYR - real return of a zero-cost portfolio with winning stocks minus losing ones. $p_{i}$-coefficient to be estimated from the multiple regressions carried out with the sample data.

Lima Júnior (2003) says that "this model is thus consistent with an equilibrium market model considering the existence of four risk factors." Alternatively, it can be seen as a performance attribution model where the coefficients and premiums indicate the proportion of return that can be attributed to strategies seeking to replicate such factors, namely a long position in shares with high beta versus shares with low beta, shares of firms with high book/market ratios in relation to those with low book/market ratios, shares of firms with low capitalization versus those with high capitalization, and finally, shares with a winning history in the recent past versus losing shares.

\subsection{History of Application of Theoretical Pricing Models in Brazil}

Matos and Neto (2008), revisiting ipsis verbis the asset pricing models à la Cahart for the Brazilian stock market for the period from 1997 to 2006, obtained results that corroborated, in qualitative and quantitative terms, those of the original works for the American market. This provides evidence of the strong explanatory power of the models analyzed, to the extent that more factors (to capture the effects of size, book/market value and momentum) are added to the CAPM.

Seeking to present a succinct history of applications of pricing models, now for portfolios, Neves (2003) stated that a first attempt was Rodrigues (2000), who tested the behavior of the returns of assets according to the three-factor model proposed by Fama and French (1993). The study's scope was limited to 1991 to 1999 , and the stability of the results was tested in two sub-periods, before and after the Real Plan ${ }^{3}$. The results demonstrated that a value strategy far outperformed a growth strategy, which presented a real loss of $40 \%$ in the period. However, the standard deviation and the betas of the value portfolios were higher than those of the growth portfolios, contrary to the results for mature markets found in Fama and French (1998), according to which value portfolios show lower risk and higher returns. Similarly, the author identified the presence of an opposite size effect to that found by other authors (Costa Jr. and Neves (2000), Halfeld and Procianoy (2000)), but in line with the results of Braga and Leal (2002) and Garcia and Bonomo (2001). The portfolio of shares of firms with high market value performed better than that of firms with low market value and lower risk, represented by the standard deviation and beta.

Just as in Costa Jr. and Neves (2000), the market beta was shown to have explanatory power with respect to specific portfolios, justifying keeping it as one of the risk factors for shares traded in the Brazilian market.

\subsection{This Work and the Related Literature}

After evaluating the asset pricing models described and the brief history of the application of these models in the Brazilian market, we decided to apply the first three models addressed: the CAPM, three-factor and four-factor models. However, we apply these models

\footnotetext{
${ }^{3}$ The Real Plan (Plano Real) was instituted in mid-1994 and finally managed to tame Brazil's rampant inflation of many years standing.
} 
differently than has been done so far. We try through these models to price and forecast the returns of stock investment funds in the Brazilian market, that is, to ascertain the factors of the respective models, as originally proposed by the authors, and from there to verify whether these factors are statistically consistent, considering the return of each of the investment funds as the dependent variable.

Our main motivation is to find out: i) initially whether it is worthwhile to use the more complex models vis-à-vis the CAPM; and ii) whether there is a need to derive a factor model as proposed by Fama and French, but one that captures specific anomalies and patterns of the mutual fund market.

\section{EMPIRICAL EXERCISE}

Our aim in this exercise or empirical test is to find out which of these models has the best pricing ability, considering the significance of the estimated coefficients (individually and together) and the coefficient of determination $\left(R^{2}\right)$, as well as the best prediction, in this case by observing the usual forecasting performance statistics. For this purpose, we use the returns of mutual funds in the Brazilian market. Therefore, we next present the database used and show how the factors were constructed that are used to process the proposed models, and describe the econometric techniques employed to process these models.

\subsection{Database}

The data used in this study come from the databases of Economática, Bloomberg, the Fortuna site and the Brazilian Institute of Geography and Statistics (IBGE). From the first database we obtained the market and book value of the firms chosen, at the end of each quarter. From Bloomberg we obtained the stock prices of each company analyzed at the end of each month, the quotations of the main index of the São Paulo Stock Exchange (IBOVESPA) and the SELIC rate (the Central Bank's benchmark rate). From the Fortuna site we obtained the quotations of the mutual funds investing in shares making up the IBOVESPA in the period analyzed. Finally, from the IBGE we obtained the consumer price index (IPCA), used to deflate the figures in the period.

For methodological reasons and questions of the facility of gathering and treating the data, we limited the scope of this study to the period from January 1997 to December 2006. We first chose a sample of the 100 most-traded stocks on the São Paulo Stock Exchange (BOVESPA). From this sample we selected stocks with at least 120 monthly quotations in the study period. We wound up working with 44 stocks, corresponding to 38 companies, as shown in Table 1 below.

Table 1: Companies and assets used in the study

\begin{tabular}{l|l|l|l}
\hline \multicolumn{1}{c|}{ Company } & \multicolumn{1}{|c|}{ Asset (Ticker) } & \multicolumn{1}{c}{ Company } & \multicolumn{1}{c}{$\begin{array}{c}\text { Asset } \\
\text { (Ticker) }\end{array}$} \\
\hline Acesita & ACES4 & Itaubanco & ITAU4 \\
Ambev & AMBV3 & Itausa & ITSA4 \\
& AMBV4 & Klabin S/A & KLBN4 \\
Aracruz & ARCZ6 & Lojas Americanas & LAME4 \\
Banco do Brasil & BBAS3 & Iochp-Maxion & MYPK4 \\
\hline
\end{tabular}


Table 1: Companies and assets used in the study (continued)

\begin{tabular}{l|c|c|c}
\hline \multicolumn{1}{c|}{ Company } & Asset (Ticker) & Company & $\begin{array}{c}\text { Asset } \\
\text { (Ticker) }\end{array}$ \\
\hline Bradesco & BBDC3 & Net & NETC4 \\
& BBDC4 & P.Acucar-CBD & PCAR4 \\
Braskem & BRKM5 & Petrobras & PETR3 \\
Brasil Telecom & BRTO4 & Paranapanema & PMAM4 \\
Celesc & CLSC6 & Marcopolo & POMO4 \\
Cemig & CMIG3 & Ipiranga Petróleo & PTIP4 \\
Copel & CPLE6 & Randon Participações & RAPT4 \\
Souza Cruz & CRUZ3 & Sadia S/A & SDIA4 \\
Siderúrgica Nacional & CSNA3 & Saraiva Livraria & SLED4 \\
Duratex & DURA4 & Suzano Papel & SUZB5 \\
Eletrobrás & ELET3 & Telemar Norte Leste & TMAR5 \\
& ELET6 & Unipar & UNIP6 \\
Eternit & ETER3 & Usiminas & USIM3 \\
Gerdau & GGBR3 & Vale R Doce & VALE3 \\
& GGBR4 & & VALE5 \\
Gerdau Metalúrgica & GOAU4 & Weg & WEGE3 \\
Guararapes & GUAR3 & &
\end{tabular}

We used the historic closing prices on the last day of each month in the referred period. The monthly return from each asset was the difference between the closing price of each month and that of the previous month, divided by this previous price. We adjusted these prices for dividends paid and any stock splits that occurred in the period. All the returns calculated, including the overall IBOVESPA and the risk-free return (SELIC rate), were deflated by the variation of the IPCA.

We drew our sample of mutual funds from those classified by the National Association of Investment Banks (ANBID) as "Ações IBOVESPA Ativo", meaning active IBOVESPA stocks, established before January 1997, administered both by independent portfolio management firms and managers linked to financial institutions.

Table 2: Mutual funds used in the study

\begin{tabular}{|c|c|c|c|c|c|}
\hline Fund Name & Administrator & $\begin{array}{c}\text { Abbreviate } \\
\text { d Name }\end{array}$ & $\begin{array}{c}\text { Accumulate } \\
\text { d Return }\end{array}$ & $\begin{array}{c}\text { Total Assets } \\
(\mathbf{R} \$)\end{array}$ & $\begin{array}{l}\text { Start of } \\
\text { Activity }\end{array}$ \\
\hline $\begin{array}{l}\text { ABN AMRO FIQ FI } \\
\text { ACOES PLUS }\end{array}$ & $\begin{array}{l}\text { ABN AMRO } \\
\text { REAL }\end{array}$ & $\mathrm{ABN}$ & $135.88 \%$ & $10,588,407.84$ & 1 Oct. 1993 \\
\hline ACOES & MELLON & Atico & $185.01 \%$ & $12,500,747.21$ & 8 Feb. 1993 \\
\hline $\begin{array}{l}\text { BNB FI ACOES } \\
\text { BRADESCO FIA }\end{array}$ & BNB & $\mathrm{BNB}$ & $175.32 \%$ & $2,937,423.55$ & 5 July 1991 \\
\hline $\begin{array}{l}\text { SUPER ACAO } \\
\text { ELITE FUNDO }\end{array}$ & BRADESCO & Bradesco & $143.53 \%$ & $62,144,895.62$ & 7 April 1994 \\
\hline $\begin{array}{l}\text { INVESTIMENTO EM } \\
\text { ACOES }\end{array}$ & ELITE & Elite & $338.54 \%$ & $4,397,641.41$ & 1 Jan. 1980 \\
\hline GALAXIA ACOES FI & ITAU & Galaxia & $778.34 \%$ & $91,772,672.88$ & 25 Sept. 1995 \\
\hline
\end{tabular}


Table 2: Mutual funds used in the study (continued)

\begin{tabular}{|c|c|c|c|c|c|}
\hline Fund Name & Administrator & $\begin{array}{l}\text { Abbreviate } \\
\text { d Name }\end{array}$ & $\begin{array}{c}\text { Accumulate } \\
\text { d Return }\end{array}$ & $\begin{array}{c}\text { Total Assets } \\
\text { (R\$) }\end{array}$ & $\begin{array}{l}\text { Start of } \\
\text { Activity }\end{array}$ \\
\hline $\begin{array}{l}\text { ITAU PRIVATE } \\
\text { ATIVO ACOES FI }\end{array}$ & ITAU & Itau 1 & $280.90 \%$ & $31,021,714.00$ & 4 April 1994 \\
\hline $\begin{array}{l}\text { ITAU EXPERTISE } \\
\text { ACOES FI } \\
\text { LEGG MASON ACOES }\end{array}$ & ITAU & Itau 2 & $514.57 \%$ & $9,394,286.15$ & 1 April 1996 \\
\hline $\begin{array}{l}\text { SUSTENT } \\
\text { EMPRESARIAL FI } \\
\text { LEGG MASON }\end{array}$ & LEGG MASON & Legg 1 & $146.60 \%$ & $121,212,541.31$ & 10 April 1986 \\
\hline $\begin{array}{l}\text { PRIVATE FOCUS } \\
\text { ACOES FIC FI } \\
\text { LEGG MASON ACOES } \\
\text { IBOV ATIVO SILVER }\end{array}$ & LEGG MASON & Legg 2 & $212.50 \%$ & $23,949,690.18$ & 1 June 1993 \\
\hline $\begin{array}{l}\text { FICFI } \\
\text { SANTANDER SUPER }\end{array}$ & LEGG MASON & Legg 3 & $161.71 \%$ & $49,314,112.96$ & 21 July 1992 \\
\hline $\begin{array}{l}\text { FI ACOES } \\
\text { SCHAHIN ACOES I }\end{array}$ & SANTANDER & Santander & $248.12 \%$ & $110,683,533.32$ & 1 Jan. 1980 \\
\hline FI & SCHAHIN & Schahin & $151.72 \%$ & $345,732.50$ & 28 Nov. 1994 \\
\hline $\begin{array}{l}\text { SLW ACOES FIA } \\
\text { SUDAMERIS FI }\end{array}$ & SLW CVC & SLW & $65.40 \%$ & $4,494,663.66$ & 8 Aug. 1994 \\
\hline $\begin{array}{l}\text { ACOES } \\
\text { INSTITUCIONAL } \\
\text { UNIBANCO }\end{array}$ & $\begin{array}{l}\text { ABN AMRO } \\
\text { REAL }\end{array}$ & Sudameris & $375.16 \%$ & $34,214,100.45$ & 23 Dec. 1996 \\
\hline $\begin{array}{l}\text { PREVIDENCIA IBOV } \\
\text { FI ACOES } \\
\text { UNIBANCO BLUE FI }\end{array}$ & UNIBANCO & Unibanco 1 & $80.52 \%$ & $49,342,724.54$ & 2 Jan. 1996 \\
\hline $\begin{array}{l}\text { ACOES } \\
\text { VOTORANTIM FI }\end{array}$ & UNIBANCO & Unibanco 2 & $110.32 \%$ & $154,794,522.47$ & 1 Jan. 1980 \\
\hline ACOES & VOTORANTIM & Votorantim & $165.76 \%$ & $14,017,009.68$ & 3 Aug. 1992 \\
\hline
\end{tabular}

We limited our sample to funds open to all investors, excluding those reserved only for qualified investors ${ }^{4}$. Thus, we obtained an initial sample of 30 stock investment funds. As mentioned, the prices of the investment shares of these funds used for analysis were obtained from the Fortuna site. However, by excluding the funds with incomplete information for the study period (January 1997 to December 2006), we narrowed the final sample down to 18 funds. Furthermore, as is standard in the literature, we used the SELIC rate, set periodically by the Brazilian Central Bank's Monetary Policy Committee (COPOM), as the risk-free rate of return.

We used the IBOVESPA to represent the market portfolio in the CAPM. The IBOVESPA is the most important indicator of the average performance of stocks in the Brazilian market. Its relevance comes from the fact it reflects the behavior of the main stocks traded on the BOVESPA, and also its tradition, because of the integrity of its historic series and the fact that it has not undergone methodological modifications since its start in 1968. Its theoretical portfolio, for the period from September through December 2006, was represented by 56 papers, weighted as shown below in Table 3 .

\footnotetext{
${ }^{4}$ As determined by the rules of the Comisão de Valores Mobiliários, or CVM, the Brazilian Securities Commission.
} 
Table 3: Composition of the IBOVESPA on December 29, 2006

\begin{tabular}{l|l|c|l|l|c}
\hline $\begin{array}{c}\text { Asset } \\
\text { (Ticker) }\end{array}$ & \multicolumn{1}{c|}{ Company } & $\boldsymbol{\%}$ & $\begin{array}{c}\text { Asset } \\
\text { (Ticker) }\end{array}$ & \multicolumn{1}{c|}{ Company } & \% \\
\hline PETR4 & PETROBRAS & 12.2792 & GOAU4 & GERDAU MET & 1.0790 \\
VALE5 & VALE R DOCE & 11.1303 & TCSL4 & TIM PART S/A & 1.0505 \\
TNLP4 & TELEMAR & 5.0171 & CCRO3 & CCR RODOVIAS & 0.9683 \\
BBDC4 & BRADESCO & 4.9593 & VCPA4 & V C P & 0.9343 \\
USIM5 & USIMINAS & 4.4258 & PRGA3 & PERDIGAO S/A & 0.9227 \\
ITAU4 & ITAUBANCO & 3.4672 & ARCZ6 & ARACRUZ & 0.8668 \\
CSNA3 & SID NACIONAL & 2.9389 & TMAR5 & TELEMAR N L & 0.8660 \\
GGBR4 & GERDAU & 2.7072 & TAMM4 & TAM S/A & 0.8450 \\
VALE3 & VALE R DOCE & 2.5487 & SBSP3 & SABESP & 0.8349 \\
BRKM5 & BRASKEM & 2.3298 & NATU3 & NATURA & 0.7135 \\
NETC4 & NET & 2.1897 & LIGT3 & LIGHT S/A & 0.7052 \\
ELET6 & ELETROBRAS & 2.1573 & BRTP4 & BRASIL T PAR & 0.6891 \\
PETR3 & PETROBRAS & 2.1151 & PCAR4 & P.ACUCAR-CBD & 0.6877 \\
CMIG4 & CEMIG & 2.0723 & ALLL11 & ALL AMER LAT & 0.6704 \\
VIVO4 & VIVO & 2.0406 & CLSC6 & CELESC & 0.6186 \\
UBBR11 & UNIBANCO & 1.9598 & KLBN4 & KLABIN S/A & 0.5975 \\
EBTP4 & EMBRATEL PAR & 1.7569 & BRTP3 & BRASIL T PAR & 0.5807 \\
ITSA4 & ITAUSA & 1.7442 & TMCP4 & TELEMIG PART & 0.5586 \\
ARCE3 & ARCELOR BR & 1.7153 & CRUZ3 & SOUZA CRUZ & 0.5459 \\
TNLP3 & TELEMAR & 1.6778 & PTIP4 & IPIRANGA PET & 0.5121 \\
CPLE6 & COPEL & 1.4697 & CESP6 & CESP & 0.4672 \\
SDIA4 & SADIA S/A & 1.3654 & TRPL4 & TRAN PAULIST & 0.4455 \\
ELET3 & ELETROBRAS & 1.3503 & TLPP4 & TELESP & 0.3997 \\
BRTO4 & BRASIL TELEC & 1.3441 & TCSL3 & TIM PART S/A & 0.3993 \\
BRAP4 & BRADESPAR & 1.3317 & ACES4 & ACESITA & 0.3695 \\
AMBV4 & AMBEV & 1.3118 & ELPL6 & ELETROPAULO & 0.3399 \\
BBAS3 & BRASIL & 1.2963 & CGAS5 & COMGAS & 0.3196 \\
EMBR3 & EMBRAER & 1.1592 & CMIG3 & CEMIG & 0.1518 \\
\hline
\end{tabular}

\subsection{Construction of the Models' Factors}

Below we specify the factors of the three asset pricing models, specified in Section 1, that are considered in this study - the CAPM, three-factor and four-factor models. These are $R M R F, S M B, H M L$ and PRIYR.

We obtained the first factor, $R M R F$, which is the basis of the CAPM, from the difference between the return on the IBOVESPA, representing the market portfolio, and the SELIC rate, the risk-free rate of return for the Brazilian market. We deflated this difference (IBOVESPA - SELIC) for each quarter by the variation of the IPCA.

The second two factors - SMB and $H M L$ - along with the factor $R M R F$, serve as the basis for the three-factor model developed by Fama and French (1993). To calculate these two factors, we used the market values (ME) of each of the 44 stocks of the 38 companies, for each quarter. Besides this, we computed the ratio between the book value (BE) and market value (ME) of each of the stocks, in each quarter, and the quarterly returns of the 44 assets.

The next step was, for each of the 40 quarters, to stratify the stocks according to market capitalization of the issuing firm (ME). This is commonly referred to as the "size" effect. Through this stratification we established two groups: the firms above and below the median of the market value to the companies in the sample. Those in the $50 \%$ of firms above 
the median are said to be big (the B in the $S M B$ variable), while those in the $50 \%$ below the median are said to be small (the $\mathrm{S}$ in $S M B$ ). Note that this creates a quarterly rebalancing for the $S$ and $B$ portfolios. The variable $S M B$ (Small minus Big), as the name suggests, is the difference between the return obtained by the $S$ and $B$ portfolios, in each quarter. The criterion for calculating the average return for each of these portfolios was the same as that used by Fama and French (1993), which is the value-weighted return, meaning the returns within the portfolios are weighted by the market capitalization of the firms.

We carried out a similar stratification, but independently and not sequentially in relation to the previous stratification, for the BE/ME variable, which represents the "value" effect, dividing this ratio into three groups according to the third and seventh deciles $(30 \%$ and $70 \%)$ of the distribution. This produced three portfolios: High $(\mathrm{H})$, in the top three deciles; Medium (M), in the middle four deciles; and Low (L), in the bottom three deciles, according to the $\mathrm{BE} / \mathrm{ME}$ ratio. Combining the two portfolios according to market capitalization with the three based on the BE/ME ratio produced six portfolios covering all the components of the sample: $B H, B M, B L, S H, S M$ and $S L$.

To assure the model's analytical ability, the independent variables must be constructed to avoid the existence of multicollinearity, since these variables will be simultaneously present in the multiple regressions. In other words, to the extent possible the difference in return of the $\mathrm{S}$ and B portfolios (the Small minus Big, or SMB variable) must be free of the effects from the BE/ME variable. The same goes for the High minus Low (HML) according to market value.

Therefore, instead of simply using the Small and Big portfolios calculated in each quarter, we used the six portfolios from the sub-stratification of the groups, through a simple orthogonalization, calculating the variables as follows, in accordance with the model developed by Fama and French (1993):

$$
\begin{aligned}
& S M B=(S L+S M+S H) / 3-(B L+B M+B H) / 3 \\
& H M L=(S H+B H) / 2-(S L+B L) / 2
\end{aligned}
$$

where:

$S L$ - portfolio composed of the stocks of small market cap firms (Small) with low book/market value (Low).

$S M$ - portfolio composed of the stocks of small market cap firms (Small) with medium book/market value (Medium).

$\mathrm{SH}$ - portfolio composed of the stocks of small market cap firms (Small) with high book/market value (High).

$B L$ - portfolio composed of the stocks of big market cap firms (Big) with low book/market value (Low).

$B M$ - portfolio composed of the stocks of big market cap firms (Big) with medium book/market value (Medium).

$\mathrm{BH}$ - portfolio composed of the stocks of big market cap firms (Big) with high book/market value (High).

Finally, we computed the fourth factor - PR1YR - which represents the momentum effect. The PR1YR associated with the three preceding factors - RMRF, SMB and HML constitute the base for processing the four-factor model presented by Carhart (1997). For each quarter we determined the return of each stock in the eleven months preceding the reference 
quarter. This allowed us to stratify the stocks according to their returns in these eleven months before the reference quarter, establishing two groups: Winners (those in the top three deciles) and Losers (those in the bottom three deciles).

\subsection{Econometric Models Utilized}

We used ordinary least squares (OLS), first proposed by the German mathematician Carl Friedrich Gauss, as our econometric estimation method. According to Gujarati (2006) "under certain assumptions, the method of least squares has some very attractive statistical properties that have made it one of the most powerful and popular methods of regression analysis."

Although this method is apparently simple, it requires some initial precautions. To make sure that there were no basic violations, we used the multivariate ARCH-LM test in the regressions of all the models to detect violation of heteroskedasticity, and the BreuschGodfrey serial correlation LM test to detect autocorrelation, applying both tests with up to five lags. For cases where there was at least one violation, we employed the variance-covariance matrix correction method proposed by Newey and West (1987).

For hypothesis testing we used the $t$-statistics and also the $F$-statistic (Wald test) to verify jointly the restrictions imposed on the coefficients of the three- and four-factor models, except alpha and beta. Below are the specifications of the three models used in the empirical tests according to the theoretical models presented in Section 2. The first model applied was the CAPM, according to the following regression:

$R_{t}^{i}-R_{t}^{\dagger}=a_{i}+\beta_{i \cdot} \cdot\left[R_{t}^{m}-R_{t}^{\dagger}\right]+\varepsilon_{t}$

where:

$\varepsilon_{t}$ - residual of the regression.

Then we tested the three- and four-factor models, according to the following respective regressions:

$$
R_{t}^{i}-R_{t}^{\dagger}=a+\beta \cdot\left[R_{t}^{m}-R_{t}^{\dagger}\right]+s \cdot S M B_{t}+h \cdot H M L_{t}+\varepsilon_{t}
$$

and

$$
R_{t}^{i}-R_{t}^{\dagger}=a+\beta \cdot\left[R_{t}^{M}-R_{t}^{\dagger}\right]+s \cdot S M B_{t}+h \cdot H M L_{t}+p \cdot P R 1 Y R_{t}+\varepsilon_{t}
$$

\section{RESULTS}

\subsection{Factors of the Models}

Table 4 presents the list of the factors for each of the 40 quarters in the study period (January 1997 to December 2006) and the returns of the IBOVESPA and SELIC in this same period, all (including the factors) deflated by the IPCA. 
Table 4: Descriptive statistics of the models' factors

\begin{tabular}{l|l|l|l|l}
\hline & RMRF & SMB & HML & PR1YR \\
\hline Mean & $0.03 \%$ & $-0.45 \%$ & $-7.99 \%$ & $0.46 \%$ \\
Standard Deviation & $19.43 \%$ & $10.35 \%$ & $8.98 \%$ & $11.10 \%$ \\
Minimum & $-37.05 \%$ & $-34.48 \%$ & $-29.72 \%$ & $-24.59 \%$ \\
Maximum & $45.44 \%$ & $24.37 \%$ & $10.33 \%$ & $19.03 \%$ \\
\hline
\end{tabular}

\subsection{Pricing the Mutual Funds}

Empirical studies have shown evidence that other attributes of assets besides beta of the CAPM can improve the estimation of expected returns. Therefore, in this study we tried to ascertain which of the three models tested (CAPM, three-factor and four-factor) performed the best in terms of pricing and in-sample forecasting, considering the observed returns of the mutual funds chosen from the Brazilian market.

Before presenting the results for each investment fund individually, we show in Table 5 and Figure 1 the accumulated return of the 18 investment funds chosen, along with the position of each of these funds in relation to the accrued result of the IBOVESPA in the study period. The stockholders equity of the funds at December 31, 2006 are also shown.

Table 5: Accumulated return of the 18 mutual funds

\begin{tabular}{|c|c|c|}
\hline Fund & Stockholders equity $(\mathbf{R} \$)^{\mathbf{a}}$ & Accumulated Return ${ }^{b}$ \\
\hline SLW & $4,494,663.66$ & $65.40 \%$ \\
\hline Unibanco 1 & $49,342,724.54$ & $80.52 \%$ \\
\hline Unibanco 2 & $154,794,522.47$ & $110.32 \%$ \\
\hline $\mathrm{ABN}$ & $10,588,407.84$ & $135.88 \%$ \\
\hline Bradesco & $62,144,895.62$ & $143.53 \%$ \\
\hline Legg 1 & $121,212,541.31$ & $146.60 \%$ \\
\hline Schahin & $345,732.50$ & $151.72 \%$ \\
\hline Legg 3 & $49,314,112.96$ & $161.71 \%$ \\
\hline Votorantim & $14,017,009.68$ & $165.76 \%$ \\
\hline BNB & $2,937,423.55$ & $175.32 \%$ \\
\hline Atiço & $12,500,747.21$ & $185.01 \%$ \\
\hline Legg 2 & $23,949,690.18$ & $212.50 \%$ \\
\hline IBOVESPA & & $229.33 \%$ \\
\hline Santander & $110,683,533.32$ & $248.12 \%$ \\
\hline Itaú 1 & $31,021,714.00$ & $280.90 \%$ \\
\hline Elite & $4,397,641.41$ & $338.54 \%$ \\
\hline Sudameris & $34,214,100.45$ & $375.16 \%$ \\
\hline Itaú 2 & $9,394,286.15$ & $514.57 \%$ \\
\hline Galaxia & $91,772,672.88$ & $778.34 \%$ \\
\hline
\end{tabular}

${ }^{\mathrm{a}}$ Position on December 31, 2006.

${ }^{\mathrm{b}}$ Period from January 1, 1997 to December 31, 2006. 


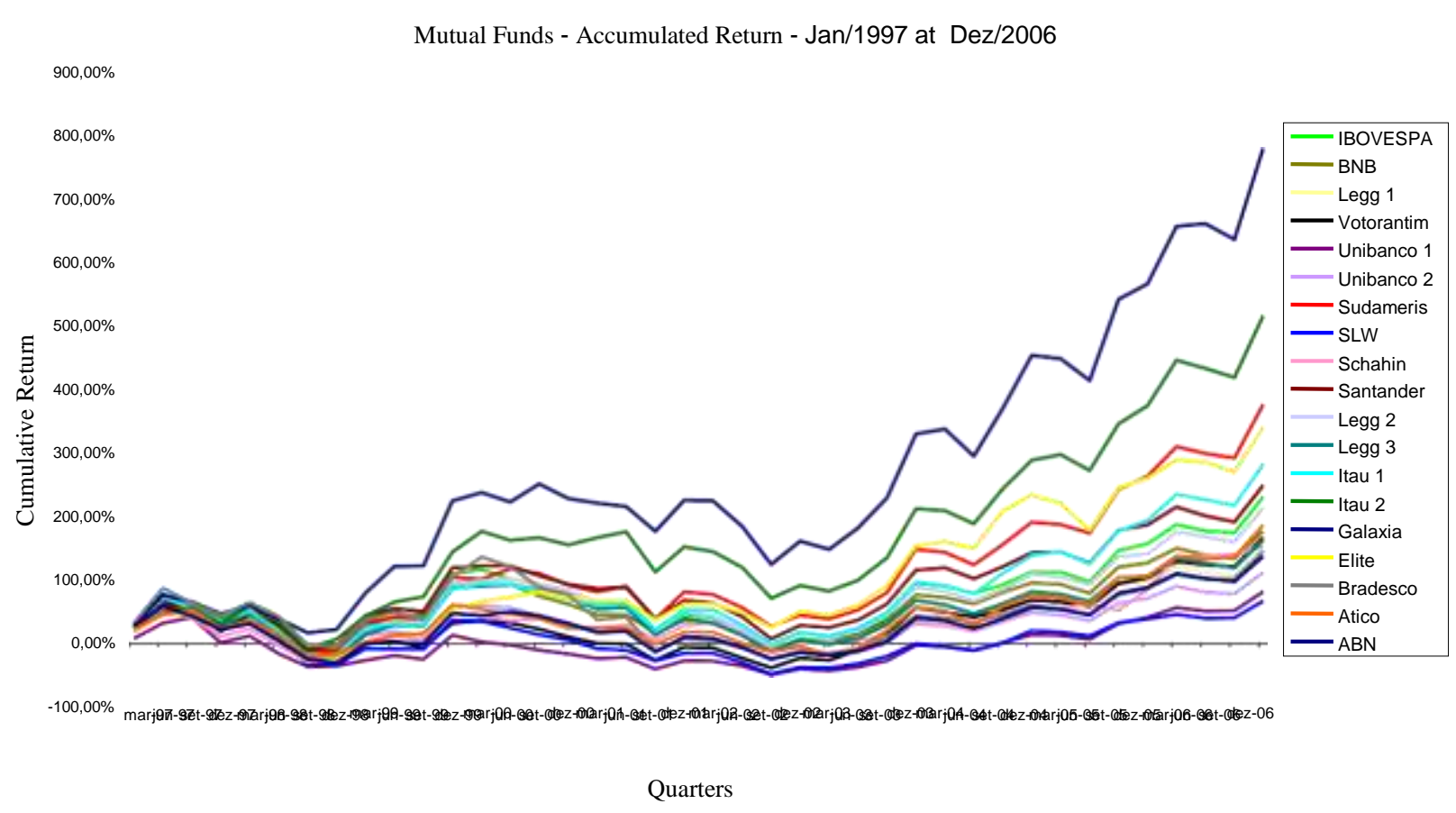

Figure 1: Accumulated return of the 18 mutual funds

An analysis of the information in Table 5 and Figure 1 shows that only six of the investment funds beat the market, represented by the accumulated return of the IBOVESPA. The other 12 funds underperformed the IBOVESPA in the period.

In the tables below we now present the results of processing the proposed models. Table 6 is an auxiliary table to indicate the relative position of each of the 18 funds studied in each of the tables showing the results of the regressions, considering the accrued return and the stockholders equity. We used this grouping scheme to verify whether there is a difference in the results of the models among funds in function of the size and return of each one, or better put, if any pattern can be identified in these results from this layout.

\section{Table 6: Relative position of the 18 mutual funds in each of the tables showing results of the regressions. ${ }^{\text {a, } b}$}

\begin{tabular}{|c|c|c|c|c|c|c|}
\hline \multirow[b]{2}{*}{$\begin{array}{c}\text { Stockholders } \\
\text { equity }\end{array}$} & \multicolumn{6}{|c|}{ Accumulated Return (relative performance) } \\
\hline & Low & 2 & 3 & 4 & 5 & High \\
\hline Small & SLW & $\mathrm{ABN}$ & Schahin & BNB & Elite & Itau 2 \\
\hline Medium & Legg 3 & Votorantim & Atico & Legg 2 & Itau 1 & Sudameris \\
\hline Big & Unibanco 1 & Unibanco 2 & Bradesco & Legg 1 & Santander & Galáxia \\
\hline
\end{tabular}

${ }^{a}$ The accumulated return is real (deflated by the IPCA) in the period from January 1997 to December $2006 .{ }^{\text {b }}$

The net asset value refers to the position of December 31, 2006. 
Tables 7, 8 and 9 present the results of the regressions for the CAPM, three-factor and four-factor models, respectively.

Table 7: Pricing test using CAPM. 1997:1 - 2006:4 - 40 observations. ${ }^{\text {a }}$

\begin{tabular}{|c|c|c|c|c|c|c|c|c|c|c|c|c|}
\hline \multicolumn{13}{|c|}{$R_{t}^{i}-R_{t}^{\dagger}=a+\beta \cdot\left[R_{t}^{M}-R_{t}^{t}\right]+\varepsilon_{t}$} \\
\hline \multirow[b]{3}{*}{ stockholders equity } & \multicolumn{12}{|c|}{ Dependent variable: excess return on the 18 investment funds classified by relative performance and value of stockholders equity } \\
\hline & \multicolumn{6}{|c|}{ relative performance } & \multicolumn{6}{|c|}{ relative performance } \\
\hline & low & 2 & 3 & 4 & 5 & high & low & 2 & 3 & 4 & 5 & high \\
\hline & \multicolumn{6}{|c|}{$a$} & \multicolumn{6}{|c|}{$p$-value $(a)$} \\
\hline small & -0.003056 & 0.005088 & $0.003738 *$ & 0.006094 & $* 0.017434$ & 0.027430 & $(0.7606)$ & $(0.5423)$ & $(0.7721)$ & $(0.3009)$ & $(0.1328)$ & $(0.0009)$ \\
\hline medium & 0.010106 & 0.009860 & $0.007904 *$ & 0.014703 & 0.019039 & 0.023260 & $(0.1137)$ & $(0.3959)$ & $(0.3441)$ & $(0.0242)$ & $(0.0031)$ & $(0.0004)$ \\
\hline \multirow[t]{2}{*}{ big } & -0.003210 & 0.001560 & $0.009057 *$ & 0.006730 & $* 0.014567$ & 0.036653 & $(0.7853)$ & $(0.7891)$ & $(0.2601)$ & $(0.2083)$ & $(0.0006)$ & $(0.0000)$ \\
\hline & \multicolumn{6}{|c|}{$\beta$} & \multicolumn{6}{|c|}{ p-value $(\beta)$} \\
\hline small & 0.930531 & 0.921727 & 0.720612 & 0.808802 & 0.756202 & 0.792529 & $(0.0000)$ & $(0.0000)$ & $(0.0000)$ & $(0.0000)$ & $(0.0000)$ & $(0.0000)$ \\
\hline medium & 0.997034 & 0.953469 & 0.777097 & 1.000822 & 0.975266 & 0.930486 & $(0.0000)$ & $(0.0000)$ & $(0.0000)$ & $(0.0000)$ & $(0.0000)$ & $(0.0000)$ \\
\hline big & 0.803632 & 0.911488 & 0.986390 & 0.944433 & 0.914165 & 0.833030 & $(0.0000)$ & $(0.0000)$ & $(0.0000)$ & $(0.0000)$ & $(0.0000)$ & $(0.0000)$ \\
\hline \multicolumn{13}{|c|}{$R^{2}$} \\
\hline small & 0.918142 & 0.940129 & 0.731147 & 0.940791 & 0.867466 & 0.890790 & & & & & & \\
\hline medium & 0.968482 & 0.930039 & 0.820860 & 0.968451 & 0.972255 & 0.952170 & & & & & & \\
\hline big & 0.814995 & 0.968029 & 0.934047 & 0.973965 & 0.974330 & 0.904986 & & & & & & \\
\hline
\end{tabular}

* Parameter not significant at 5\%. P-value in parentheses.

${ }^{a}$ Estimation technique: OLS with standard error consistent for heteroskedasticity and serial autocorrelation, as proposed by Newey and West (1987). 
Table 8: Pricing test using the 3-factor model of Fama and French (1993). 1997:1 - 2006:4 - 40 observations. ${ }^{\text {a, } b}$

$$
R_{t}^{i}-R_{t}^{f}=a+\beta_{i} \cdot\left[R_{t}^{M}-R_{t}^{f}\right]+s_{i} \cdot S M B_{t}+h_{i} \cdot H M L_{1}+\varepsilon_{t}
$$

Dependent variable: excess return on the 18 investment funds classified by relative performance and value of stockholders equ ity

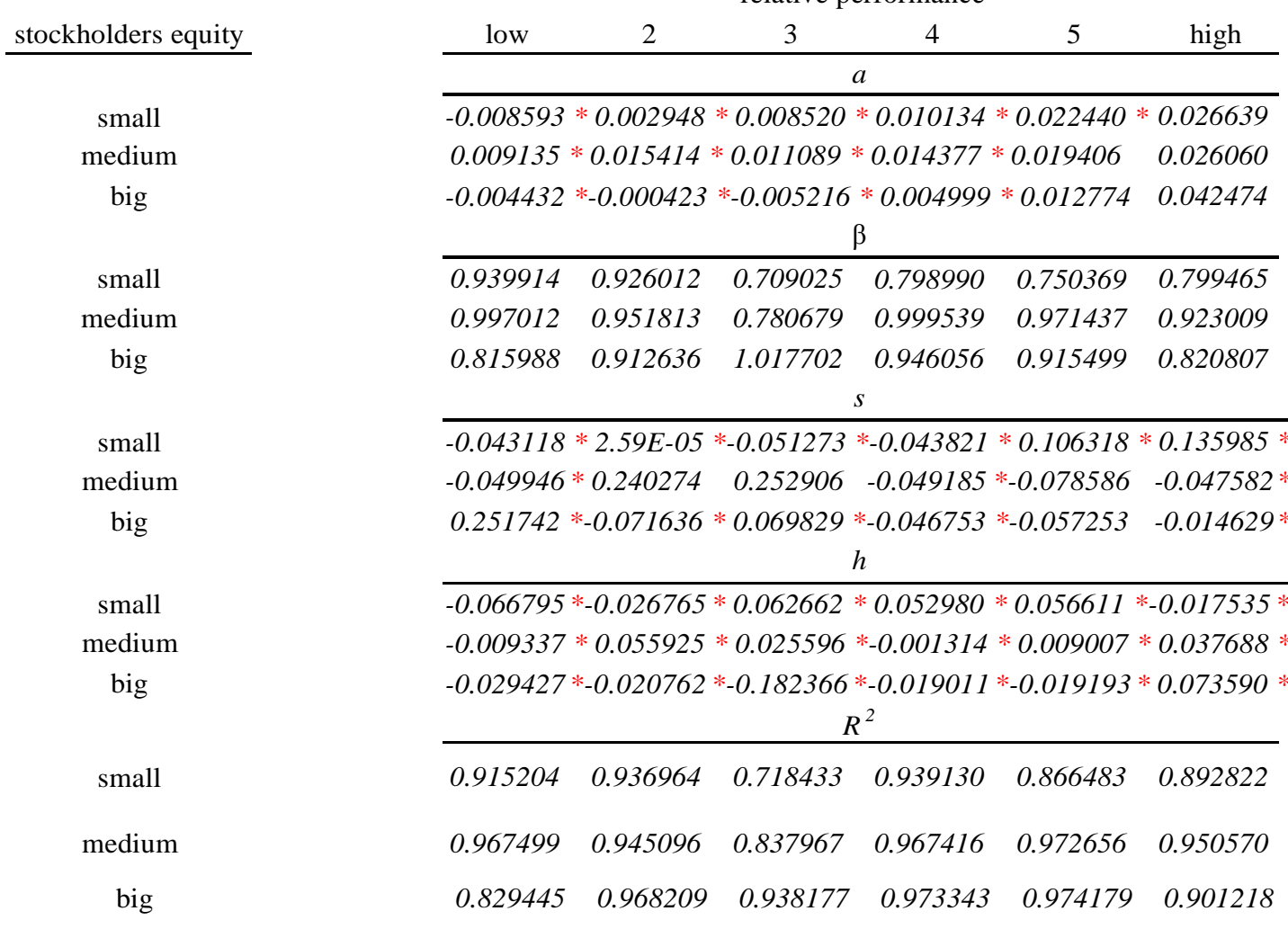

* Parameter not significant at 5\%. P-value in parentheses.

${ }^{a}$ Estimation technique: OLS with standard error consistent for heteroskedasticity and serial autocorrelation, as proposed by Newey and West (1987).

${ }^{\mathrm{b}}$ In the Wald test the F statistic is reported along with the respective $\mathrm{p}$-value in parentheses.

\begin{tabular}{|c|c|c|c|c|c|}
\hline low & 2 & 3 & 4 & 5 & igh \\
\hline \multicolumn{6}{|c|}{$p$-value $(a)$} \\
\hline$(0.5112)$ & $(0.8274)$ & $(0.6140)$ & $(0.2614)$ & $(0.1398)$ & $(0.0169)$ \\
\hline$(0.3020)$ & $(0.1209)$ & $(0.2909)$ & $(0.1062)$ & $(0.0389)$ & $(0.0220)$ \\
\hline$(0.7225)$ & (0.9497) & $(0.7109)$ & $(0.5487)$ & $(0.0350)$ & $(0.0001)$ \\
\hline \multicolumn{6}{|c|}{$p$-value $(\beta)$} \\
\hline$(0.0000)$ & $(0.0000)$ & $(0.0000)$ & $(0.0000)$ & $(0.0000)$ & $(0.0000)$ \\
\hline$(0.0000)$ & $(0.0000)$ & $(0.0000)$ & $(0.0000)$ & $(0.0000)$ & $(0.0000)$ \\
\hline$(0.0000)$ & $(0.0000)$ & $(0.0000)$ & $(0.0000)$ & $(0.0000)$ & $(0.0000)$ \\
\hline \multicolumn{6}{|c|}{$p$-value $(s)$} \\
\hline$(0.5986)$ & $(0.9996)$ & $(0.5705)$ & $(0.4093)$ & $(0.2221)$ & $(0.1371)$ \\
\hline$(0.3458)$ & $(0.0038)$ & $(0.0258)$ & $(0.3490)$ & $(0.0028)$ & $(0.3357)$ \\
\hline$(0.1323)$ & $(0.0802)$ & $(0.2624)$ & $(0.3329)$ & $(0.0124)$ & $(0.8892)$ \\
\hline \multicolumn{6}{|c|}{$p$-value $(h)$} \\
\hline$(0.4570)$ & $(0.7886)$ & $(0.5858)$ & $(0.4310)$ & $(0.5135)$ & $(0.7855)$ \\
\hline$(0.8901)$ & $(0.4335)$ & $(0.6850)$ & $(0.9845)$ & $(0.8794)$ & $(0.6643)$ \\
\hline$(0.7541)$ & $(0.7322)$ & $(0.0996)$ & $(0.7567)$ & $(0.7088)$ & $(0.1973)$ \\
\hline \multicolumn{6}{|c|}{ Wald Test - Ho: $s=0, h=0$} \\
\hline 0.685524 & 0.036526 & 0.430944 & 0.506134 & 0.974152 & 1.163062 \\
\hline $\begin{array}{l}(0.5103) \\
0.463456\end{array}$ & $\begin{array}{r}(0.9642) \\
5.558814\end{array}$ & $\begin{array}{r}(0.6532) \\
3.831391\end{array}$ & $\begin{array}{r}(0,6070) \\
0.450128\end{array}$ & $\begin{array}{r}(0.3872) \\
5.513153\end{array}$ & $\begin{array}{l}40) \\
861\end{array}$ \\
\hline 1.0 .632896 & $\begin{array}{r}(0.0079) \\
1.69851\end{array}$ & $\begin{array}{l}(0.0310) \\
1.877044\end{array}$ & $\begin{array}{l}(0.6411) \\
0.544943\end{array}$ & $\begin{array}{l}(0.0082) \\
3.485286\end{array}$ & $\begin{array}{l}(0.6054) \\
0.922334\end{array}$ \\
\hline$(0.3106)$ & (0.1973) & $(0.1677)$ & $(0.5846)$ & $(0.0413)$ & $(0.4068)$ \\
\hline
\end{tabular}


Table 9: Pricing test using the 4-factor model of Cahart (1997). 1997:1 - 2006:4 - 40 observations. a, b

\begin{tabular}{|c|c|c|c|c|c|c|c|c|c|c|c|c|}
\hline \multirow[b]{2}{*}{ stockholders equity } & \multicolumn{6}{|c|}{ relative performance } & \multicolumn{6}{|c|}{$\begin{array}{l}\text { olders equ ity } \\
\text { relative performance }\end{array}$} \\
\hline & low & 2 & 3 & 4 & 5 & high & low & 2 & 3 & 4 & 5 & high \\
\hline & \multicolumn{6}{|c|}{$a$} & \multicolumn{6}{|c|}{$p$-value (a) } \\
\hline small & -0.007229 & $* 0.003248 *$ & $0.007079 *$ & $0.009954 * 0$ & $.024648 *$ & 0.026676 & $(0.5749)$ & $(0.8085)$ & $(0.6878)$ & $(0.2589)$ & $(0.1516)$ & $(0.0317)$ \\
\hline medium & 0.007352 & $* 0.013935 *$ & $0.013759 *$ & $0.012589 *$ & $.019435 *$ & 0.025684 & $(0.3659)$ & $(0.1486)$ & $(0.2660)$ & $(0.1248)$ & $(0.0508)$ & $(0.0157)$ \\
\hline \multirow[t]{2}{*}{ big } & -0.004240 & $* 0.000694 *$ & $-0.002661 *$ & $0.003399 *$ & 0.013441 & 0.045246 & $(0.7480)$ & $(0.9215)$ & (0.8495) & $(0.6266)$ & $(0.0250)$ & $(0.0002)$ \\
\hline & 0935045 & \multicolumn{4}{|c|}{$\beta$} & & \multicolumn{6}{|c|}{$p$-value $(\beta)$} \\
\hline small & 0.935945 & & & 0.799514 & 0.743947 & 0.799357 & $(0.0000)$ & $(0.0000)$ & $(0.0000)$ & $(0.0000)$ & $(0.0000)$ & $(0.0000)$ \\
\hline medium & 1.002198 & 0.956118 & 0.772913 & 1.00474 & 0.971354 & 0.924103 & $(0.0000)$ & $(0.0000)$ & $(0.0000)$ & $(0.0000)$ & $(0.0000)$ & $(0.0000)$ \\
\hline \multirow[t]{2}{*}{ big } & 0.815429 & 0.909387 & 1.010268 & 0.950712 & 0.913558 & 0.812744 & $(0.0000)$ & $(0.0000)$ & $(0.0000)$ & $(0.0000)$ & $(0.0000)$ & $(0.0000)$ \\
\hline & \multicolumn{6}{|c|}{$s$} & \multicolumn{6}{|c|}{$p$-value $(s)$} \\
\hline small & -0.010941 & $* 0.007116 *$ & $-0.085258 *$ & -0.048069 & $0.158382 *$ & $0.136863 *$ & $\begin{array}{l}(0.9005) \\
\end{array}$ & $(0.9250)$ & $(0.4764)$ & $(0.4602)$ & $(0.1352)$ & $(0.1280)$ \\
\hline medium & -0.091995 & $* 0.205375$ & 0.315873 & -0.091354 & -0.077907 & $-0.056455 *$ & $(0.0870)$ & $(0.0082)$ & $(0.0144)$ & $(0.0849)$ & $(0.0265)$ & $(0.4505)$ \\
\hline \multirow[t]{2}{*}{ big } & 0.256269 & $*-0.045295$ & $0.130096 *$ & -0.084501 & -0.041518 & $* 0.050740 *$ & $(0.1593)$ & $(0.3004)$ & $(0.0634)$ & $(0.0958)$ & $(0.2605)$ & $(0.6125)$ \\
\hline & \multicolumn{6}{|c|}{$h$} & \multicolumn{6}{|c|}{$p$-value $(h)$} \\
\hline small & -0.048137 & $*-0.022654$ & 0.042956 & $0.050517 *$ & $0.086800 *$ & $-0.017026 *$ & $(0.5627)$ & $(0.8150)$ & $(0.7423)$ & $(0.4219)$ & $(0.3787)$ & $(0.8234)$ \\
\hline medium & -0.033719 & $* 0.035689 *$ & $0.062106 *$ & $-0.025765 *$ & $0.009400 *$ & $0.032543 *$ & $(0.6115)$ & $(0.6284)$ & $(0.4442)$ & $(0.7026)$ & $(0.8776)$ & $(0.6550)$ \\
\hline \multirow[t]{2}{*}{ big } & -0.026803 & $*_{-}-0.005488$ & $-0.147420 *$ & $-0.040899 *$ & -0.010069 & $* 0.111493 *$ & $(0.7959)$ & $(0.9168)$ & $(0.1681)$ & $(0.4681)$ & $(0.8367)$ & $(0.1083)$ \\
\hline & \multicolumn{6}{|c|}{$p$} & \multicolumn{6}{|c|}{$p$-value $(p)$} \\
\hline small & 0.059567 & $* 0.013125 *$ & -0.062914 & -0.007865 & 0.096382 & $0.001625 *$ & $(0.3204)$ & $(0.8886)$ & $(0.5741)$ & $(0.9081)$ & $(0.4772)$ & $(0.9860)$ \\
\hline medium & -0.077844 & $*-0.064607$ & $0.116567 *$ & -0.078064 & $0.001257 *$ & -0.016426 & $(0.1811)$ & $(0.3197)$ & $(0.2912)$ & $(0.1763)$ & $(0.9823)$ & $(0.8652)$ \\
\hline \multirow[t]{2}{*}{ big } & 0.008380 & $* 0.048763 *$ & $0.111570 *$ & $-0.069882 *$ & $0.029128 *$ & $0.121013 *$ & $(0.9159)$ & $(0.3538)$ & $(0.1315)$ & $(0.2352)$ & (0.5507) & $(0.1651)$ \\
\hline & \multicolumn{6}{|c|}{$R^{2}$} & \multicolumn{6}{|c|}{ Wald Test - Ho: $s=0, h=0, p=0$} \\
\hline small & 0.913716 & 0.935210 & 0.711782 & 0.937412 & 0.866174 & 0.889760 & $\begin{array}{c}0.677746 \\
(0.5715)\end{array}$ & $\begin{array}{l}0.024701 \\
(0.9947)\end{array}$ & $\begin{array}{l}0.375910 \\
(0.7709)\end{array}$ & $\begin{array}{l}0.335169 \\
(0,8000)\end{array}$ & $\begin{array}{l}1.039556 \\
(0.3871)\end{array}$ & $\begin{array}{r}0.862236 \\
(0.4698)\end{array}$ \\
\hline medium & 0.968034 & 0.944588 & 0.837939 & 0.967946 & 0.971875 & 0.949231 & $\begin{array}{c}1.239899 \\
(0.3100)\end{array}$ & $\begin{array}{c}3.665093 \\
(0.0214)\end{array}$ & $\begin{array}{l}2.953984 \\
(0.0458)\end{array}$ & $\begin{array}{c}1.24374 \\
(0.3086)\end{array}$ & $\begin{array}{l}3.803465 \\
(0.0185)\end{array}$ & $\begin{array}{r}0.343113 \\
(0.7943)\end{array}$ \\
\hline big & 0.824595 & 0.967988 & 0.939377 & 0.973903 & 0.973686 & 0.903139 & $\begin{array}{c}0.780748 \\
(0.5127)\end{array}$ & $\begin{array}{l}1.193912 \\
(0.3263)\end{array}$ & $\begin{array}{l}2.740883 \\
(0.0579)\end{array}$ & $\begin{array}{l}1.225071 \\
(0.3151)\end{array}$ & $\begin{array}{l}2.776924 \\
(0.0556)\end{array}$ & $\begin{array}{r}1.002884 \\
(0.4031)\end{array}$ \\
\hline
\end{tabular}

* Parameter not significant at 5\%. P-value in parentheses.

${ }^{a}$ Estimation technique: OLS with standard error consistent for heteroskedasticity and serial autocorrelation, as proposed by Newey and West (1987).

${ }^{\mathrm{b}}$ In the Wald test the F-statistic is reported along with the respective p-value in parentheses.

BBR, Braz. Bus. Rev. (Engl. ed., Online),

Vitória, Vol. 6, No. 1, Art. 2, p. 21 -41, Jan-Apr 2009

www.bbronline.com.br 
All the tables show the values of the models' coefficients and their respective $p$ values, as well as the coefficients of explanation $R^{2}$. Besides this, Tables 8 and 9 show the results of the Wald test, since the factor models are characterized by the inclusion of two and three regressores, respectively. As explained above, the layout of the tables follows that in Fama and French (1993), to provide better visualization, enabling identification of a pattern for the investment funds.

The results of Table 7, corresponding to the CAPM, show that Jensen's $\alpha$ parameter is only statistically significant for the mutual funds with high stockholders equity and relatively high performance. This is an initial indication that the CAPM is not the best for investment funds with this profile, exogenously identified, providing arguments for the derivation of more appropriate models.

In Tables 7, 8 and 9, the market parameter $\beta$ is statistically significant at $5 \%$ for all the mutual funds analyzed, indicating the robustness of the relevance of the market-beating return as an explanatory variable. The coefficients of determination $\mathrm{R}^{2}$ of all the investment funds analyzed show good results, the majority of them above $80 \%$. Thus, it is not possible to detect any improvement of this indicator when one uses the CAPM or the factor models, according a mutual funds pattern.

Tables 8 and 9 report the results of the tests using the factor models of Fama and French (1993) and Cahart (1997), respectively. With respect to Jensen's $\alpha$, the insertion of more factors as regressors appears to be relevant in the sense of better capturing the sources of risk associated with the investment funds with higher relative stockholders equity and better performance, with a gradual decline in the number of funds for which this parameter is significant. However, the factor models present problems related to the significance of precisely the coefficients of the factors inserted in these models.

In the three-factor model, only four of the eighteen funds show a significant (at 5\%) parameter associated with size, $s$, while the other parameter, $h$, which measures the sensitivity to the book/market value effect, is not significant for any of the funds studied. ${ }^{5}$

Table 9 shows that the inclusion of the momentum effect substantially increases the number of mutual funds for which the size effect is significant, but the book/market ratio continues to be insignificant, and more troubling, the momentum effect is also not significant at $5 \%$.

According to the Wald test, the null hypothesis that the parameters associated with the new factors are not jointly significant is rejected in only a few isolated cases.

To summarize, in the Brazilian stock market the insertion of the two additional factors proposed by Fama and French (1993) and the momentum factor proposed by Carhart (1997) appear to be highly relevant in the pricing of shares, making them fundamental in forecasting in the cross-sectional dimension. However, when analyzing investment funds, involving time series regressions, the results obtained here for the value and significance of the coefficients associated with the risk factors, the joint test and the value of $\mathrm{R}^{2}$ suggest that the capital asset pricing model is not as good at capturing the sources of common risk among the investment funds with higher stockholders equity and greater accumulated profitability. It improves with the incorporation of the size effect, but this comes with problems of significance of the parameters. Is this the expected result?

This is certainly no trivial question. As Fama and French themselves argued, even when these factor models are used to price Fama-French portfolios in an in-sample exercise, good performance still cannot be assured. In Fama and French (1993), the results clearly

\footnotetext{
${ }^{5}$ For one of the investment funds the $h$-parameter is significant, but only at $10 \%$.
} 
indicate this improvement when using risk factors that capture the size and book/market value effects. Our exercise here is an out-of-sample one for dynamic portfolios, and it is even less trivial that these models are always superior to the CAPM.

Further evidence is provided from the analysis of the results obtained, listed in Table 10, for the in-sample empirical forecasting exercise.

Table 10: In-sample prediction performance of the pricing models of the investment funds studied - 18 observations. ${ }^{a}$

\begin{tabular}{c|c|c|c}
\hline \multicolumn{4}{c}{ Measures of prediction performance $^{\text {a }}$} \\
\hline \multirow{2}{*}{ Models } & Root mean square error & \# Best Results/18 & \# Worst Results/18 $^{\text {CAPM }}$ \\
\hline Three-factor & $0.0000297384361037772 \%$ & $7 / 18$ & $6 / 18$ \\
Four-factor & $\mathbf{0 . 0 0 0 0 3 1 8 5 2 1 9 9 6 0 0 0 6 6 8 \%}$ & $2 / 18$ & $8 / 18$ \\
\hline
\end{tabular}

${ }^{\mathrm{a}}$ The prediction performance statistics show the comparison between the observed returns and those predicted by the models for the 18 investment funds studied.

As can be observed in Table 10, all the models performed well in absolute terms, because the performance statistics assumed very low values when compared with the statistics of other models, and in particular considering that each of the eighteen investment funds studied has a dynamic portfolio, meaning the portfolio makeup certainly changed during the ten years studied (January 1997 to December 2006).

The results are shown for the use of three prediction measures: the root mean square error, the highest ratio of best prediction results and the lowest ratio of worst prediction results. For these three measures, the robust evidence is that the four-factor model performed the best, and the three-factor model the worst.

Two other observations should be made. First, it should be recalled that in estimating the three models, we followed the extensive literature on asset pricing for Brazil and assumed the SELIC rate as a proxy for the risk-free rate of return. This is a limitation of this work because there can be no sovereign risk in the risk-free rate of return ${ }^{6}$. For the case of Brazilian public bonds this is not true, although the country risk is at historically low levels, and has recently been upgraded to investment grade ${ }^{7}$, a clear signal of foreign investors' perception of the solid fundamentals of the Brazilian economy. Therefore, a possible extension of this work is to test the robustness of the results obtained here using the risk-free rate of return for the Brazilian market derived by Simonassi and Matos (2008). They state that the variation of this rate is at a level historically below the SELIC rate one.

In the second place, further study can verify whether or not the size of total assets and performance of the investment funds influence the performance of the pricing models endogenously, as evidenced in the preliminary results of Linhares, Matos and Zech (2009).

6 "In fact you could almost say that we live again in a two-super-power world. There is the US and there is Moody's. The US can destroy a country be leveling it with bombs. Moody's can destroy a country by downgrading its bonds." Thomas Friedman.

7 Classification of papers (by the ratings) considered by the international community as "prudent" or "secure". 


\section{CONCLUSIONS}

As explained above, our intention was to find out which of the three models studied (CAPM, three-factor and four-factor) is most effective at pricing and predicting the returns of mutual funds in the Brazilian market.

The results indicate that the CAPM is least able to capture the sources of common risk among investment funds with higher stockholders equity and greater accumulated return in relation to the market. This performance improves with the inclusion of other factors, particularly the size effect, but this is accompanied by problems of significance of the parameters, a result corroborated by in-sample predictions. This result cannot be considered a definitive answer, but it does suggest a promising direction for future studies, in which these aspects of investment funds can be better accommodated by using a model along the lines of Fama and French, but in which the risk parameters capture these aspects endogenously in an in-sample pricing exercise.

\section{REFERENCES}

BLACK, F.; Jensen, M.; Scholes, M. The Capital Asset Pricing Model: Some EmpiricalTests. In: JENSEN, M. Studies in the Theory of Capital Markets, New York: Praeger, 1972. p. 79-121.

BODIE, Z.; Merton, R. Finanças. Translation by James S. Cook. 1st. ed. rev. and expanded. Porto Alegre: Bookman Editora, 2002. 456 p.

BONOMO, M. Finanças Aplicadas ao Brasil. 2nd ed. Rio de Janeiro: Editora FGV, 2004. 480 p.

CARHART, M. M. On Persistence in Mutual Fund Performance. Journal of Finance, New York, v. 52, n. 1, p. 57-81, March 1997.

FAMA, E. F.; French, K. The Cross-section of Expected Stock Returns. Journal of Finance, New York, v. 47, n. 2, p. 427-465, jun.1992.

FAMA, E.; French, K. Common risk factors in the returns on stocks and bonds. Journal of Financial Economics, New York, 33, 3-56. 1993.

FAMA, E.; French, K. Value versus growth: The international evidence. Journal of Finance, New York, 53, 1975-1999. 1998.

GUJARATI, D. Econometria Básica. Translation by Maria José Cyhlar Monteiro. 4th ed. Rio de Janeiro: Elsevier and Editora Campus, 2006. 812 p.

JEGADEESH, N.; Titman, S. Returns to buying winners and selling losers: Implications for stock market efficiency. Journal of Finance, 48, 65-91. 1993.

LINHARES, F.; Matos, P.; Zech, Gustavo. On the Empirics of the Mutual Funds Puzzling Aspects. Working paper, CAEN/UFC. 2009.

MARKOWITZ, H. M. Potfolio Selection. Journal of Finance, v.7, p.77-91, 1952. 
MATOS, P.; Neto, A. Revisitando o Modelo de Apreçamento de Ativos a la Cahart para o Mercado Acionário Brasileiro, Dissertação de Mestrado Profissional em Economia da UFC, 2008.

NEVES, M. Três Ensaios em Modelos de Apreçamento de Ativos. Doctoral Thesis in Business Administration - Universidade Federal do Rio de Janeiro - UFRJ, Instituto COPPEAD de Administração. Rio de Janeiro, 2003. 132 p.

ROSS, S. The arbitrage theory of capital asset pricing. Journal of Economic Theory, v. 13, p.341-360, 1976.

SIMONASSI, A.; MATOS, P. On the Empirics of the Risk-Free Rate: The Brazilian Case. Working paper, 2008.

VARGAS, G.; LEAL, R. Gestão de Investimento e Fundos. São Paulo: Atlas, 2006. 480 p. 